18

\title{
SPECIAL OPERATIONS FORCES AND AFGHAN LOCAL POLICE PROGRAMS
}

\author{
Donald C. Bolduc and Chris Hensley
}

U.S. Special Operations Forces (SOF) deployed to Afghanistan in October 2001 to topple the Taliban regime. With the fall of the Taliban and the establishment of a new Afghan government in December 2001, the SOF campaign quickly transitioned from unconventional warfare to counterinsurgency and foreign internal defense employing regular and irregular Afghan forces to improve security.

Security forces are considered "irregular" when they do not fall within the formal security establishment, even if sanctioned and supported by the state. They are more of a militia as opposed to a standing and professional police or military force. ${ }^{1}$ The fall of the Taliban left a security void, and the coalition and new Afghan government determined they had to build Afghanistan's security apparatus from scratch. As a result, they often had to rely on irregular forces to provide security in the more remote areas of the rugged country.

Over the next decade, SOF attempted to address rural insecurity and instability through the integration of regular and irregular forces. Unfortunately, multiple attempts to create irregular security forces ended in failure. The lack of success for an "integrated" approach resulted from two dynamics: Afghan national, provincial, and district governance dysfunction exacerbated by corruption and a rural population characterized by fierce independence and a historical pattern of fighting against the centralization of authority.

But these earlier experiences slowly revealed the costs, benefits, and risks associated with irregular force constructs. Lessons learned from earlier attempts—along with support from academics, innovative SOF leaders, and geopolitical conditions-coalesced in 2009 to enable the development and application of the Village Stability Operations (VSO) and Afghan Local Police (ALP) program, the first truly successful irregular security force since the war's start. It was a balanced "bottom up" and "top down" counterinsurgency approach, with the objective of connecting traditional tribal governance at the village level to the central government at the district and provincial levels.

Key to this objective was empowering rural populations to govern and defend themselves while stabilizing and improving the basic functions of district governance. The approach was unique in that it attempted to integrate security, development, and governance through a balanced, mutually supportive method that would address the underlying sources of instability in rural Afghanistan. The VSO/ALP construct may not be a panacea for all security and stability issues, but this chapter presents it as an effective construct in Afghanistan.

This chapter highlights the evolution of irregular forces in selected areas of Afghanistan in hopes that the lessons learned may prove valuable when considering irregular force employment in similar environments. It starts by discussing some of the implications of a parochial-based security force design. Next, it describes 
some of the earlier irregular security forces: Afghan Security Force, Afghan highway patrolmen, Afghan National Auxiliary Police, and the Afghan Public Protection Program. It then details the development of the Village Stability Operations program and the Afghan Local Police.

\section{Implications of a parochial-based security force design}

Following the defeat of the Taliban, Afghan stakeholders signed the Bonn Agreement authorizing statebuilding efforts by the international community. ${ }^{2}$ It requested support building a security force but did not specify size or type. The international community decided upon a large, centralized Western military design intended to support a strong, democratically elected central government.

Although well intended, this decision failed to fully appreciate the unique nature of Afghanistan's polity, culture, and social structure. Moreover, the force was not designed to counter the Taliban's rural-based insurgency. As a result, the operational performance of the newly created Afghan National Security Forces was inadequate to deal with the re-emerging insurgent threat.

The only successful attempts at relative central authority in Afghanistan's history were those that employed what Thomas Barfield called the "Swiss Cheese" model. He explained that successful rulers and their succeeding dynasties understood that only the most populated and economically prosperous segments of Afghanistan could be centrally governed. Other geographically disconnected areas had to be left to their own tribal and clan forms of governance. ${ }^{3}$

In contrast, central authority is "universal and absolute" in his "Processed American Cheese" model. ${ }^{4} \mathrm{He}$ explained that central authority was never historically extended to distant and remote areas in Afghanistan unless they posed a direct challenge to the state. When they posed a challenge, successful rulers confronted these distant threats by empowering their rival clans and tribes, preventing their access to urban markets, or attacking these challengers to demonstrate the cost of their actions. All of the regimes that tried to govern these distant locals-Amanullah Khan from 1919-1929, the People's Democratic Party of Afghanistan from 1978-1992, and the Taliban from 1996-2001-were ultimately overthrown. ${ }^{5}$

Both Afghan and coalition political representatives, as well as senior military leaders, viewed irregular forces as antithetical to the Western model of a stable democratic state. They were perceived as proxies for warlords or other malevolent actors and a potentially lethal threat to democracy. Critics pointed to the rise of warlords after the Soviet withdrawal as setting conditions for the Taliban takeover of Afghanistan.

Opposition to employment of irregular forces and the lack of a corresponding counterinsurgency strategy strangled attempts at pursuing "bottom-up" irregular force approaches. Some military units attempted to create local, irregular security forces, but these programs slowly deteriorated due to a lack of financial, material, or political support from the international community, the Afghan central government, and those in the military community who believed that a counterterrorism approach was the solution to Afghanistan's problems.

Coalition efforts initially focused on building the Afghan National Army and Afghan National Police. As the Taliban and other insurgent groups grew from 2003-2005, however, coalition operational priorities began to shift toward countering the insurgent threat, which came at the expense of training the army and national police. Regardless, the national army and national police were never going to be large enough to adequately address a rural-based and geographically dispersed insurgent threat.

As a result, United States and coalition efforts to counter insurgent threats and train their partners simultaneously produced an operational methodology focused on short-duration combat operations to clear the enemy with no ability to hold terrain. This led to a counterproductive cycle: coalition and Afghan army elements would clear an area and return to their bases, and then the Taliban would return and eventually reseed the previously cleared territory. The Afghans living in these rural areas recognized that neither the Afghan government nor the Taliban were winning, which resulted in "fence sitting" by a majority of the rural populace. Neutrality ensured their survival. 
The absence of a comprehensive counterinsurgency strategy and long-term vision created a cycle of frustration: American units rotated into Afghanistan, observed the current situation, and formulated plans that would support their tactical priorities, at least for the duration of their stay. This produced objectives and end-states that were tactical and short term: clear a particular geographic area of insurgents, improve a few tactical capacities of a partner, and sprinkle in civil-military development efforts.

Conventional forces would complete their respective rotations and either never return to Afghanistan or return many years later. This cycle prevented senior leaders from recognizing and altering the approach. Conversely, many SOF elements returned year after year. It was not uncommon for some SOF units and leaders to have completed as many as six or eight rotations. This rotational frequency helped reveal the lack of an effective counterinsurgency campaign strategy, assessment framework, and operational progress.

\section{Afghan Security Force (2004-2005)}

Special Forces detachments operating in 2003-2004 recognized a need for Afghan forces to expand their combat power, protect outposts, and gather intelligence, so they began recruiting and employing irregular forces. Over time, these irregular forces became increasingly capable. By 2004, they were labeled the Afghan Security Force. Together with coalition SOF, these forces effectively targeted and neutralized many insurgent fighters and facilitators. Unfortunately, they could not hold terrain, and coalition forces did not focus sufficient attention on the development of the Afghan army. Compounding the challenge was the U.S. invasion of Iraq that made Afghanistan a supporting effort.

Afghan President Hamid Karzai and other government officials became increasingly averse to irregular forces. The Afghan Security Force, however, filled a critical operational need for coalition SOF operating in remote rural areas. The Special Forces detachments developed trust and formed close bonds with their Afghan Security Force partners by living, eating, laughing, and sharing with them. This directly translated into greater security and operational effectiveness. In time, however, the detachments were redirected to partner with the Afghan National Army, and the Afghan Security Force was restricted to base security functions. By early 2006, the 2,000-man force was demobilized. ${ }^{6}$

\section{Afghan highway patrolmen (2006-2007)}

When Lieutenant Colonel Donald C. Bolduc returned to Kandahar in July 2006 to take command of Task Force-31 (TF-31), which had responsibility for southern Afghanistan, some of his Special Forces detachments were on their fourth or fifth rotations. ${ }^{7}$ Predictably, the task force found itself having to regain lost terrain it had secured just months earlier. Having participated in the capture of Kandahar and Karzai's reintroduction to the country in 2001, Bolduc implicitly understood the critical role tribal alliances played in the effort then and what that meant now.

Recognizing the weight of the task ahead, Bolduc encouraged his company and detachment commanders to leverage tribal structures during their rotation in Kandahar, Uruzgan, Zabul, Helmand, Nimroz, Farah, and Herat provinces. This section will focus on the efforts in Uruzgan Province.

Beyond the organic TF-31 elements, coalition forces in Uruzgan Province included 150 Texas National Guard soldiers, U.S. civil-military personnel, Australian special operations elements, and 200 Afghan army soldiers. These units would have to reorganize, unify, and synchronize efforts to improve security conditions. Luckily, the leaders figured out a way to complement each other to achieve a "unity of effort" despite the lack of a "unity of command." Additionally, the 30-day area assessment determined that tribal alliances and power brokers would prove instrumental.

Jan Mohammed, the Karzai-appointed Uruzgan governor, had supported SOF's entry into the country in 2001 but subsequently established a kleptocracy, severely alienating the provincial population. This only fed the Taliban's narrative, enabling them to expand their influence in the province exponentially. 
Conditions were so adverse that coalition forces could not travel safely to the governor's mansion a quarter of a mile from their outpost, and local Afghan security guards hired by the Provincial Reconstruction Team ${ }^{8}$ were found diagramming the coalition bases. Recognizing that significant manpower would be required to alter these conditions, the task force engaged with local officials and tribal leaders.

The advanced operations base (AOB), the name for a deployed Special Forces company, discovered that the governor's right hand-man, Matiullah Khan-who was a member of the Pashtun subtribe known as the Popalzai-was also the provincial tribal leader. By 2005, SOF had learned that capable leaders were critical to making security and stability improvements, so the AOB immediately set out to partner with Khan. Replacing Mohammed was necessary to establish government legitimacy and improve security. The SOF relationship with Khan would be the decisive factor in marginalizing the governor and accomplishing this delicate task.

Khan, the illiterate son of a farmer who had inherited his tribal appointment, maintained power by crushing challengers. He was a product of the conditions and society around him. But Khan had close ties to Karzai, who was also a member of the Popalzai subtribe. ${ }^{9}$ Khan had personally helped Karzai reach Kandahar in 2001. His relationship with Karzai and role as the provincial tribal leader ensured formal and informal governance connectivity. For these reasons, Khan was best positioned to help the United States achieve its objectives in Afghanistan.

Khan certainly recognized that a relationship with U.S. and coalition forces could render legitimacy, financial gain, and political power. His loyalties rapidly realigned with the coalition. Soon, he openly defied Mohammed's requests that ran counter to SOF interests. He reported the governor's attempts to discredit the coalition politically, his leaking of intelligence concerning SOF missions to the Taliban, and his narcotics trafficking. Eventually, in 2006, Karzai removed Mohammad from office.

While developing this relationship with Khan and the various Popalzai district elders, coalition SOF pressured Taliban networks using lethal and non-lethal means to create the time and space necessary for governance development efforts. Coalition and Afghan forces pushed the Taliban out of population centers and persistently targeted them in the surrounding countryside. This enabled Khan to establish rings of security checkpoints around Tarin Kowt, Uruzgan's provincial capital.

As this Popalzai security force demonstrated an increased ability to secure the province, SOF sought approval from the Afghan central government to designate Khan and his men official "Afghan highway patrolmen." The short-lived Afghan Security Force program demonstrated the need to formalize an irregular force to ensure its long-term viability.

Unlike the Afghan National Army, the highway patrolmen came from the province and provided needed access to and support from the local population. In addition to building trust between the Afghan government and the local population, it also provided better intelligence to the coalition. As security improved, it also allowed the Provincial Reconstruction Team to take on more reconstruction efforts.

Khan and the highway patrolmen provided a tribal-based means to secure and hold terrain and maintain civil order. Yet Khan still lacked sufficient control in more distant parts of the province. Additionally, power struggles continued. Smaller subtribes-the Barakzai and Alokazai-complained of being threatened, attacked, or mistreated by the Popalzai.

Economic development remained slow. Some large-scale infrastructure projects occurred, but investment in micro-development was lacking. Bolduc attempted to create village reconstruction teams to work hand in hand with the Provincial Reconstruction Teams, but he lacked the implementation time before the battalion rotated out of Afghanistan.

While the approach certainly had its faults, traditional and formal governance finally began to intersect in central Uruzgan. The effort simply needed to be nurtured and codified. In the years to come, Khan continued to support coalition SOF until he was assassinated by a Taliban suicide bomber in Kabul in 2015. ${ }^{10}$ 
The experiment also reinforced the theory that a counterinsurgency strategy that balances counterterrorism operations with formal and informal partner development efforts is effective in setting conditions for partner operational independence. Unfortunately, given the lack of a governing long-term theater strategy, after TF-31 departed, its replacements reverted to a counterterrorism centric approach. This ultimately ceded terrain and popular influence back to the Taliban.

\section{The Afghan National Auxiliary Police (2006-2007)}

During the 2006 deployment, it became clear to Bolduc that the national police could not hold ground won during clearing operations, nor could the Afghan National Army, as they were needed for clearing operations elsewhere in the country. Thus, Bolduc sought out Kandahar Governor Asadullah Khalid to build a tribal force - the Afghan National Auxiliary Police - that would partner with TF-31 Special Forces detachments to ensure the long-term security of Panjwai, a district in Kandahar Province.

This plan would leverage traditional local governance structures to establish governance, protect the populace, separate the threat from the populace and their operating areas, and force an elusive enemy to expose itself. The governor agreed to support the proposal and even traveled with the detachments in Panjwai and surrounding districts to help get the program started.

Tribal elders, the national police, and Governor Khalid were responsible for vetting the tribal candidates. The governor held shuras (traditional tribal meetings) with local elders to gain their support. He also served as the conduit with the Ministry of Interior and President Karzai to obtain national support for the program. Formal and informal governance began to intersect as top-down support was assured.

Despite the support, the program did not necessarily go smoothly; International Security Assistance Force (ISAF) elements responsible for providing official police training resisted and disparaged the program, alleging it would compete with provincial police forces for funding and equipment. In their view, it was an illegitimate militia that would damage the Afghan government in the long term. As a result, funding for the program was temporarily delayed.

TF-31 immediately turned to their partners in the Central Intelligence Agency, who agreed to fund the program until a formal system could be instituted through the Ministry of Interior. One detachment was assigned responsibility for designing a three-week training program, which included human rights and law of war training. Within five months, TF-31 had generated approximately 1,000 Afghan National Auxiliary Police. The detachments lived with this force to improve operational functionality.

From the onset, it was designed as a temporary force to hold key terrain in and around Kandahar, allowing the national police and the national army to focus elsewhere. Eventually, National Auxiliary Police members were permitted to attend formal police and army training to become part of the formal Afghan security architecture. The ISAF Regional Command South commander, Dutch Major General Van Loon, commended TF-31 for this initiative and advocated its formalization.

Over time, the program expanded into Helmand, Zabul, Nimroz, and Herat provinces, with the force growing to 9,000 officers. ${ }^{11}$ Yet the lack of a formal, overarching ISAF counterinsurgency strategy prevented rotating units from focusing on long-term objectives. As a result, after TF-31 departed, incoming SOF units returned once more to a counterterrorism-centric strategy, focused more on targeting the Taliban directly and less on building partner capacity.

The program also suffered from a lack of national-level ministerial and ISAF oversight and support. When the Afghan government deployed the National Auxiliary Police beyond their geographical areas of tribe, clan, and qawm (a social unit in Afghanistan) linkage, it began to collapse as National Auxiliary Police elements began to create more problems than they resolved. The same set of circumstances that had negatively affected the Afghan Security Force contributed to the collapse of the Auxiliary Police. 


\section{The Afghan Public Protection Program (2009-2010)}

The abandonment of the National Auxiliary Police program in 2008 prevented the Afghan security architecture from holding terrain and protecting local populations in rural areas. ISAF and SOF elements continued to clear terrain of insurgents only to have them return. In essence, units were fighting a decade-long war one year at a time. Since the ISAF leadership and some SOF units continued to ignore the underlying causes of instability and failed to build an Afghan-based capacity to hold key terrain, conditions necessitated another irregular force solution. Thus, Special Forces in Wardak Province, led by Major Brad Moses, initiated the Afghan Public Protection Program in March 2009.

Given the proximity of the Taliban to Kabul (Wardak Province is directly west of Kabul), ISAF, the Ministry of Interior, the Ministry of Defense, and the National Defense Services backed the program. As a result, the Ministry of Interior formalized the Public Protection Program from the start. Moses established an Afghan-led vetting process and a three-week training program and fought for resources through the Ministry of Interior.

By 2010, it had grown to approximately 1,200 personnel with a target of 8,000 (200 per district), and it secured the major roads running south and southeast from Kabul, critical infrastructure (bridges, dams, district centers), and the home villages of the participants. ${ }^{12}$ This bottom-up local security organization complemented Afghan National Security Forces and succeeded at holding terrain and developing stability in villages and districts. The security environment in Wardak soon began to improve. It appeared the program might succeed, but a few factors emerged that would negatively affect it.

First, the international community and human rights organizations held its controversial leader, former Taliban member Ghulam Mohammed Hotak, in contempt. Instead of viewing this as a potential opportunity for reintegration, many asserted he was recruiting active Taliban. ${ }^{13}$ Some could not discern that local villagers joined any group that presented the greatest opportunity for their personal survival. Changing sides was part and parcel of tribal culture and a survival mechanism. Whatever their previous allegiances may have been, Hotak and his men aligned with the Afghan government.

Second, the lack of consistent resourcing facilitated the decline and eventual closure of the program.

Third, ISAF redirected SOF from the Public Protection Program to the Afghan National Civil Order Police program. The Civil Order Police was an expeditionary formal police unit that was designed to deploy throughout the country in response to instability. It was created as an elite gendarmerie and initially conceived of as a riot control force but was also assigned to replace district-level police who were away for collective training. ${ }^{14}$ SOF mentoring was seen as indispensable to the program's success. Thus, ISAF transferred the Public Protection Program mission to the conventional forces.

Given the nascent nature of the Public Protection Program and lack of capacity of the conventional forces to mentor and adequately train the force, logistical support degraded, pay became irregular, and coalition support during enemy engagements eroded. The Public Protection Program's distrust with the Afghan government and coalition grew, and they were left wondering why they had been abandoned. Eventually, Public Protection Program leader Ghulam Hotak quit out of frustration.

In hindsight, it is clear that operational conditions in Afghanistan demanded the employment of an irregular force and traditional governance approaches, but senior leaders did not hear calls for change. Yet a growing chorus called for change. ${ }^{15}$ Seth G. Jones noted, "Some of America's most seasoned diplomats and military commanders in Afghanistan did understand the country, but they could not get through to their leaders, who were initially uninterested in nation building and distracted by Iraq." 16

Jones compared the American experience to previous ones. He described the common challenges foreign invaders in Afghanistan have faced since Alexander the Great in $330 \mathrm{BC}$. The challenges were surprisingly similar to those of the United States in 2009. Jones outlined some of the specific causes of American stagnation: insufficient coalition manpower, diversion of U.S. forces and resources to Iraq, corruption, poor Afghan leadership, Taliban exploitation of a religious ideology, and a safe haven in Pakistan. Jones helped persuade senior leaders that a greater balance was needed regarding bottom-up and top-down approaches. ${ }^{17}$ 
At this time, international resolve to stay the course in Afghanistan began to wane; calls for withdrawal and frustration over the lack of progress mounted. ${ }^{18}$ After eight years of fighting, most Afghans polled viewed their government as generally ineffectual and corrupt. ${ }^{19}$ The coalition continued to pursue an enemy-focused operational approach, development efforts were marginally effective, and Afghan governance and security capacities stagnated. There were some successes: cities expanded, more children attended school, medical care improved, and some Afghan special operations units demonstrated success. On the whole, however, the Taliban grew in strength and influence.

\section{Village Stability Operations and the Afghan Local Police (2009-2014)}

Beginning in 2009-2010, U.S. Special Operations Command's (SOCOM) initiative to embed SOF detachments in contested villages across Afghanistan proved one of the most effective engagement methods employed in the theater. The Local Defense Force initiative, which morphed into Village Stability Operations, placed highly trained SOF units in rural villages to live and work among the villagers and advance stability in the region.

Village stability worked "backwards": first establishing stability in the villages and then connecting village governance to the districts and the provinces. Investing in villages required rigorous analysis and a long-term commitment; it was also socially tiring. But the rewards were worth the risk: the central government could not create stability without support from the villages.

\section{The Local Defense Initiative (2009)}

In mid-2009, General Stanley McChrystal assumed command of ISAF. An innovative problem solver, ${ }^{20}$ he rapidly redefined how to fight the campaign. He directed the creation of a population-centric campaign strategy and prioritized coalition efforts toward Afghan security and governance capacity development. He drove unification of U.S. and coalition SOF efforts. This forced the coalition to focus more on long-term objectives and encouraged new approaches to that end. ${ }^{21}$

With supportive ISAF leadership, it appeared that an irregular force redux might finally succeed. This time it was Special Forces officer Scott Mann who presented the idea to Brigadier General Ed Reeder, the Combined Forces Special Operations Component Command-Afghanistan (CFSOCC-A) commander. Reeder supported the approach, and through his leadership and vision, the Local Defense Initiative was born.

The Local Defense Initiative concept was straightforward: Special Forces detachments would attempt to gain the trust of local elders, live in their villages, develop local security forces, and support tribal council governance reformation and local economic development. It was hoped that this would permit the reemergence of rural governance to manage security and ultimately provide conflict resolution and development opportunities.

The coalition effort in Afghanistan was at a pivot point. Success required a full-court press, as well as proven, innovative leaders. With McChrystal at the helm, a SOF commander was finally in charge of the campaign in Afghanistan, a campaign that was from the beginning an unconventional one. To round out the SOF team, Brigadier General Scott Miller replaced Reeder to lead CFSOCC-A, and Bolduc returned to assume command of Combined Joint Special Operations Task Force-Afghanistan (CJSOTF-A) underneath him. This partnership transformed SOF operational progress and ultimately defined how U.S. and coalition SOF would organize and operate in Afghanistan for years to come.

Three weeks prior to assuming command, Bolduc conducted a comprehensive operational assessment of the command across Afghanistan. One of the shortcomings that it identified was the need for a more uniform focus on consistent partnership development across all operating units regardless of how far flung or disparate the environment. 
The Local Defense Initiative lacked operational level command emphasis, resulting in the absence of a codified operational methodology; organizational supporting framework; and a formalized narrative explaining its purpose, intent, and benefit to the aggregate Afghan security architecture. CJSOTF-A simply had not developed a larger organizational supporting plan or strategy that prioritized efforts in relation to McChrystal's design.

Bolduc designated the Local Defense Initiative program as CJSOTF-A's main effort. This realigned CJSOTF-A's operational priorities more effectively with McChrystal's population-centric campaign strategy. Additionally, it served to communicate to all subordinates what was paramount to organizational operational success. As the staff shifted its effort from deliberate attack planning to the Local Defense Initiative, development gaps and shortfalls became readily apparent. The training of formal security force partners such as the Afghan Commando Corps, their special forces detachments, and special police units had never received sufficient attention. ${ }^{22}$

The Commandos played a critical role in establishing and maintaining the conditions necessary for large-scale development and sustainment of Afghanistan's irregular forces. But they remained incapable of managing force management administration, logistics, and command and control functions independently, so the coalition SOF elements managed these institutional functions for them in large measure. CJSOTF-A took a number of steps to address these shortfalls and recognized that the Local Defense Initiative program would not be self sustaining until institutional reforms with the formal SOF units were addressed.

Organizational restructuring helped address some institutional challenges. No longer could the training of Afghan SOF be an additional task for one of the operational SOF battalions; it required a dedicated training command. Bolduc selected Lieutenant Colonel Miguel Howe to design and build the Afghan Special Operations School. ${ }^{23}$ CFSOCC-A required the Afghan Ministry of Defense to participate in the school's design and development to inculcate a sense of responsibility for its management and to facilitate an eventual seamless transition.

It became apparent that the evolving Special Operations School would require a significant amount of support and coordination with the Ministry of Defense and the Afghan government. Bolduc requested that the school be re-aligned from the CJSOTF-A to the CFSOCC-A, given Miller and his staff maintained the relationship with the Ministry of Defense. This allowed the CJSOTF-A to focus more attention on the Local Defense Initiative.

To be successful, Bolduc would have to leverage the support of multiple Afghan ministries and a host of U.S. interagency actors and non-governmental organizations. His command eventually integrated these stakeholders into a global network to help analyze causes of rural instability and address them. It leveraged students from the Naval Postgraduate School in Monterey, California, to help draft the Local Defense Initiative's operational methodology. Lessons from the previous attempts had also demonstrated the importance of early Afghan branding to the longevity of the program. While the program had a name, the forces needed a name other than "Local Defense Forces."

\section{Establishing VSO/ALP (2010)}

Bolduc and Miller worked with ISAF and the Afghan government to determine an acceptable name for the program. President Karzai was uncomfortable with militias and insisted on an Afghan government connection to a local defense force. CJSOTF-A effectively communicated the program's purpose and demonstrated to the Karzai administration that there were no connections to non-governmental militias. ${ }^{24}$ In August 2010, Karzai signed a presidential decree authorizing Village Stability Operations and the Afghan Local Police. ${ }^{25}$ This decree was essential for securing the Afghan government's buy-in.

CFSOCC-A selected the highest-priority locations for VSO, which included an assessment of the human terrain to determine whether a particular village would accept the proposition of defending themselves. Once selected, the village held a jirga or shura (tribal meetings) to decide whether to accept the 
proposition. If accepted, a Special Forces detachment was sent to live among the population to build the security force and promote governance and development. Village elders hand-selected the ALP members, intentionally selecting a group to represent the ethnic and tribal cross-section of the local populace.

The initial implementation strategy resembled the operational phases used in 2005-2007- "shape, clear, hold, build, and transition" - although in practice, the "clear" area may have initially been very small. The detachments "shaped" the security environment, which allowed them to "hold" the village and surrounding territory through influence, deterrence, and the advent of a local police or militia. ${ }^{26}$ When a VSO site was first established, the vast majority of SOF efforts were directed toward understanding the threat while simultaneously training the ALP force. Over time, units conducting VSO found themselves in the unique position to expand their involvement with the local populace from one narrowly focused on security to include governance and economic development.

In the build phase, the detachment connected the village or villages under its control with the district and provincial government. This phase resembled the larger control hub or civic action platform utilized in the Civilian Irregular Defense Group from Vietnam. ${ }^{27}$ The villages, local population, and local police had to feel that they were part of the larger national government. This in turn established a sense of ownership in the legitimacy of the system and feelings of nationalism and created the impression that the local villagers are firmly committed to a goal greater than themselves - in essence, the establishment of the social contract.

The final phase of the VSO strategy was the transition phase. This phase was one of the most delicate of the operation and can be compared to the latter stages of the civilian defense strategy when Vietnamization occurred. During the transition phase, after certain metrics of success were met, the Special Forces detachment would hand the local defense force over to the national police or the Afghan National Army - or the local forces would disband, disarm, and reintegrate into society. It is important to place the same level of emphasis on this phase of the operation to avoid the fate of the Montagnards and their treatment by the South Vietnamese army. By the summer of 2010, CFSOCC-A had established 20 VSO sites. ${ }^{28}$

Codifying all aspects of the program and having a "brand" with the approval of the Afghan government proved essential in winning the support of the ISAF commander, the U.S. Agency for International Development, the Department of State, and ultimately funding from the U.S. Congress. Bolduc also adapted CJSOTF-A's organizational structure to provide the top-down support that had always been missing or unsustainable in previous programs. He formed a cell in the plans section of his staff to help with the logistics, administration, and resourcing of the program. This cell was directly linked to the CFSOCC-A headquarters in Kabul and coalition liaison officers in the Ministry of Interior. It eventually integrated liaisons arrayed at provincial and district centers as well.

Bolduc also directed his staff to develop a 24-month campaign support plan to establish continuity and unity of effort for the VSO/ALP program and partner development efforts; he sought to mitigate some of the friction from units rotating every six months. The 24-month campaign plan established clear lines of effort, intermediate military objectives, and supporting effects. The assessment cell applied the appropriate metrics to determine what was and was not working, which improved operational level decision-making. It marked the first time that population-centric metrics were provided to demonstrate clear progress in security, governance, and development. As a result, General David Petraeus, who had replaced McChrystal as the ISAF commander, made VSO/ALP a top priority. ${ }^{29}$

Bolduc also transformed the CJSOTF-A operations center into a situational awareness room. This reflected his view that the purpose of the command was to enable its subordinate elements. This allowed the headquarters to move valuable manpower and intellectual capital from the arguably bloated headquarters to subordinate units where they were desperately needed.

Bolduc invited coalition and Afghan special operations forces to join the CJSOTF-A staff. He gave each a desk in the situational awareness room: Emirates, Australians, Canadians, Afghan Commandos, and French personnel. Bolduc extended the same invitation to the U.S. interagency community. This 
broadened operational synchronization and improved effectiveness. It also resulted in an expansion of combat (and non-combat) power. As allies felt more involved, they increasingly volunteered to support various missions and initiatives. NATO SOF targeted Taliban networks in areas that complemented CJSOTF-A operations, while the United Arab Emirates even volunteered to conduct VSO.

The command's collective partner development and operational efforts improved dramatically. Miller and his staff in Kabul rapidly effected change for detachments on the ground across Afghanistan. For example, ineffective district police chiefs and governors were now removed in a month or two; previously, it took six, if they were removed at all. Equipping and pay issues were now resolved within days versus months.

Improved reporting helped to reveal that the planned re-vetting of the ALP and other Afghan partners had not occurred. Although they had been thoroughly vetted during the recruiting process, they had not been re-vetted later. The initial vetting began with tribal elder recommendation, national police endorsement, biometric enrollment, drug/medical screening, psychological testing, and interviews. The names of individuals who passed initial screening were then forwarded to the Ministry of Interior in Kabul for final approval before training commenced. But after initial screening, the Afghans had no mechanism to weed out individuals who later became liabilities.

More emphasis should have been placed on re-vetting given the high threat of insurgent infiltration. Due to the need to rapidly build the ALP capability, Special Forces detachments were often operating as split teams. Instead of all 12 detachment members being located together, which is the norm, they were split to double the ALP capacity. But given the remoteness of their locations, it brought additional risk.

Beyond helping to identify potential insider threats, the re-vetting also served to verify accurate ALP accounting for pay, which limited the potential for graft and helped cleanse the program of those violating drug and behavioral standards. The re-vetting process took one month to complete, and while it eliminated only a small percentage of participants, it improved force capability and management accounting.

Due to better information flow, another gap was identified: detachments encountered difficulty acquiring intelligence from women and children in communities in which they resided. Given that women and children represented over $50 \%$ of the population, detachments were missing valuable intelligence on insurgent activities and insights into tribal and political matters. They were also the ones most impacted by development efforts: schools, clinics, security, and improvements in agricultural production.

As a result, CJSOTF-A attached experienced female medical service non-commissioned officers to the SOF detachments in Uruzgan and Kandahar provinces. The results proved promising: team situational awareness improved, and micro-economic development expanded. In time, SOF formalized the program into what became Cultural Support Teams, and the initiative would ultimately influence the Pentagon's thinking regarding the roles of women in combat. The program had its share of ups and downs as it evolved, but it did validate the operational advantages to integrating female service members for counterinsurgency and stability operations. ${ }^{30}$

\section{VSO/ALP progammatics, structure, and enablers}

As organizational structures and supporting initiatives were refined, the command's supporting capacities expanded as well. The enterprise learned the importance of cultural demographic analysis, persistent stakeholder engagement, liaisons partnered with district and provincial authorities, and the need to control program growth to ensure quality. CJSOTF-A conducted a deliberate tribal analysis, often lasting weeks or months, to select VSO/ALP sites based on their potential. The assessments were critical to understand every aspect of social structure, stakeholder influence, geography, and threat conditions.

Over time, a number of recurring characteristics emerged, such as: evolution occurred more rapidly when existing tribal structures existed, tribal homogeneity acted as a growth catalyst, and living between 


\section{Special Operations and Afghan police}

competing subtribes avoided negatively impacting natural balances of power. Codifying these and other findings helped optimize the program's methodology.

The command developed a comprehensive information operations plan and a structured media engagement plan. Another element vital to the expansion and success of the program was a tiered engagement strategy. At the tactical level, detachments conducted radio broadcasts and face-to-face engagements with local stakeholders and populations. At the operational level, CJSOTF-A briefed interagency and Afghan ministerial elements. Opening the program to media scrutiny, early and often, enabled the command to help drive the narrative versus having to spend significant amounts of time defending the program.

As the program expanded, it became glaringly apparent that most Afghan district officials, and some provincial officials, were woefully inept at executing the responsibilities of their offices. Yet the program was dependent on these officials to succeed. Thus, CJSOTF-A embedded liaison teams-Provincial Advisory Teams and District Advisory Teams - to improve the various district and provincial offices.

These liaison officers mentored district governors and police chiefs on security issues and helped them develop processes and mechanisms to ensure the ALP were adequately equipped and paid on time. A capable district office was critical to transferring control of the ALP to the Afghans so the detachment could transition to a new location to expand the program. If the Afghan government consistently supported the ALP, and district representatives and tribal elders routinely met with them, then success had been achieved. Some sites still failed, but in a majority of cases, the advisory teams managed to improve performance of district and provincial centers.

To avoid the fate of earlier security efforts, CJSOTF-A sought to institutionalize the program. While some stakeholders did not fully recognize or agree with the ALP/VSO construct, they could not argue with its success on the ground. It was so effective that the Taliban viewed the ALP program as a direct threat to their strategic success and their number-one priority to attack. ${ }^{31}$

Likewise, Miller wanted to ensure institutional success, so he established a senior leader mentoring program where he and other senior leaders directly mentored their Afghan counterparts. The multilateral engagement strategy that was formed months earlier and had advocated support for the program produced dividends. Popular opinion of Afghan provincial governance improved. ${ }^{32}$

When Petraeus took command of ISAF in 2010, the ALP program had already improved security in some areas. He visited VSO sites in Kandahar and Kunar, and he was so impressed with the potential of the program that he personally advocated for its expansion. Petraeus called it a "game changer" and characterized it to the U.S. Congress as an essential piece of the Afghan security architecture necessary to improve security and stability. ${ }^{33}$

In June 2011, Petraeus and Afghan officials agreed to increase the authorized strength of the ALP from 10,000 to 30,000 despite only having 6,500 police at 41 sites. ${ }^{34}$ Without Petraeus' support, the program certainly would not have evolved to become a pillar of the Afghan security architecture. Once the new target had been established, CFSOCC-A and CJSOTF-A furiously analyzed how to accomplish this in a manner consistent with the program's tenets. It was fortuitous that the 24-month campaign support plan was already in place because it provided the framework; however, the mechanics of the expansion required significant analysis. Most importantly, how would the command maintain program standards, a quality over quantity conundrum?

Probably the greatest determinate of program success was direct, long-term SOF mentorship. A RAND study would later reveal that successful sites required an average of 15 months of direct mentoring. ${ }^{35}$ Longterm SOF partnering improved both combat skills and behaviors. This did as much to legitimize the force as successfully defending against Taliban incursions. CFSOCC-A requested an additional Army Special Forces battalion to meet growth demands, but SOCOM was unable to fulfill the request due to other requirements in Iraq and Afghanistan.

Ultimately, SOCOM approved an additional Special Forces battalion headquarters, but it did not answer the need for operational teams. After studying the issue, Bolduc and the battalion commanders agreed to 
"split team" operations to double the operational capacity of Special Forces, although it increased tactical and operational risk. SOCOM also provided Navy SEAL teams and Marine Special Operations Teams. This may not sound unusual in today's context, but at the time, it was contentious at senior command levels in the special operations community.

CFSOCC-A also requested a conventional infantry battalion to augment the CJSOTF-A. ${ }^{36}$ This was unprecedented and led to a shift in conventional forces and SOF interoperability. The intent was to further split the Special Forces detachments and augment them with infantry squads to maximize growth, maintain program standards, and ensure adequate force protection. But this was not a mission for which infantry forces had ever been trained.

The concept was ultimately approved, although grudgingly by some senior conventional force leaders worried that the unit would be relegated to fire base guards and taken advantage of by SOF. In the summer of 2011, Lieutenant Colonel Curtis Buzzard and an infantry battalion from the 82nd Airborne Division deployed to support the VSO mission in northern Afghanistan. ${ }^{37}$

The skeptics were proven wrong, as it proved a success. It demonstrated that non-traditional SOF and conventional forces command and control relationships can work. In northern Afghanistan, the infantry battalion headquarters, supported by an Army Special Forces company headquarters, commanded multiple Special Forces detachments, a SEAL platoon, an infantry rifle company, a heavy weapons company, and elements of a forward support company and a headquarters company.

It worked remarkably well and validated the value of an adaptive methodology in a complex and dynamic environment. The combined effects of such force restructuring and employment methodology enabled the VSO/ALP mission to advance and more importantly redefine future SOF and conventional forces operational constructs and command and control approaches. ${ }^{38}$

The program's operational success fueled additional support for the program. The VSO program was a relative bargain when compared to the cost of other security programs. The development and employment of an ALP officer cost one-fourth that of a national police officer and one-sixth that of an Afghan National Army soldier. ${ }^{39}$ It proved an effective and economical approach to rural security, a significant advantage in an economy where $76 \%$ of its gross domestic product came from international donors. ${ }^{40}$ Security solutions needed to be cost effective to be viable in the long term.

Unlike the national police and national army, the ALP demonstrated sustained improvements in rural security. According to the 2011 Afghan National Safety Office, insurgent attacks dropped 42\% in Kunduz, $64 \%$ in Baghlan, and $76 \%$ in Takhar. ${ }^{41}$ Seeing this data and the projected $\$ 180$ million a year price tag for 30,000 ALP, the U.S. Congress approved multi-year funding. ${ }^{42}$

The rapid expansion and success of the ALP required a significant amount of logistical support. Lieutenant Colonel Ron Reagan, the CJSOTF-A support battalion commander, contracted small fixed-wing aircraft to support troop movements, air dropped thousands of tons of supplies and materials each month, and contracted and acquired a fleet of ground and all-terrain vehicles.

Simultaneously, Mann designed an innovative and enhanced SOF pre-deployment training and education program. Detachments learned about Afghan history and culture from Afghans and esteemed academicians, gaining insight into causes of rural instability. They heard from recently returning VSO SOF operators on what does and does not work. Mann transformed pre-deployment training from basic combat skill training to something more akin to a graduate-level course. Operators routinely commented that it was the best pre-deployment education that they had received in their careers. ${ }^{43}$

As Bolduc and Miller rotated out of Afghanistan in the summer of 2011, the program had a solid foundation and a long-term supporting plan, significant improvements in security had been achieved, and U.S. and coalition SOF were more operationally integrated. Institutional evolution advanced with Afghan special operations partners, and they were more effectively recruiting, training, resourcing, and executing command and control responsibilities. 
Bolduc returned in the summer of 2012 for his ninth deployment to Afghanistan to command CFSOCC-A. By the end of 2012, the program had grown to 18,000 and was operational at 92 sites, ${ }^{44}$ but Bolduc was in a race against the clock. He was trying to build VSO/ALP capability to mitigate the effects of the U.S. drawdown while trying to transition the program to the Afghans at the same time.

Since the program's inception, the Barack Obama administration had surged forces into Afghanistan, and in 2011, their withdrawal began. With the signing of the strategic partnership agreement between the United States and Afghanistan in May 2012, it was expected that nearly all U.S. forces would be out by the end of 2014. ${ }^{45}$ This decision forced U.S. military leaders to make hard choices on the prioritization of efforts.

Bolduc hurried to ensure that the Ministry of Interior could independently manage the program. Due to the success of the program and unprecedented security gains, there were calls, even in the midst of the transition, to expand the ALP to $45,000 .{ }^{46}$ But it was clear to all parties that SOF would no longer be able to live in the villages with the ALP and mentor them, and the Ministry of Interior would have to assume this role with the help of Afghan special forces. By the end of 2014, the transition was complete.

Unfortunately, without SOF mentorship and support, the program could not sustain the gains it had made. By 2019, many of the security gains achieved by the program had been lost, with the Taliban controlling $14 \%$ of the country's districts and another $29 \%$ remaining contested-controlled by neither the Taliban nor the government. ${ }^{47}$

\section{Conclusion}

Developing successful irregular force programs is an exceedingly difficult and complex process, but, as demonstrated in Afghanistan, it can be an extremely effective and economical way to fill a security gap. But building an effective program is not easy, as demonstrated by the failures of the Afghan Security Force, the Afghan highway patrolmen, the Afghan National Auxiliary Police, and the Afghan Public Protection Program. These failures, and the success of the VSO/ALP program, demonstrate that success requires three essential elements: international support, government support, and a willing populace. Village stability is a building-block component that ultimately contributes to security at the district, provincial, and national levels.

The VSO/ALP model demonstrates the importance of possessing an in-depth historic and cultural understanding of the operational environment. The VSO/ALP program highlights the advantage of outlining a comprehensive supporting framework that integrates bottom-up and top-down efforts seamlessly. It evidences the vital need for a multi-dimensional engagement strategy. The program succeeded because it addressed rural security and instability challenges through the reformation of tribal governance and security mechanisms supported through a central authority at the district and provincial levels as part of a population-centric counterinsurgency strategy.

$\mathrm{VSO} / \mathrm{ALP}$ represents the quintessential SOF counterinsurgency and irregular warfare mission, combining both direct and indirect approaches in a balanced and integrated approach. It played to SOF organizational strengths: adaptability, fungibility, small-unit decentralized execution, and specialized skill-set and tradecraft capabilities. Additionally, it demonstrated the effectiveness of a command and control construct, where SOF is supported by conventional forces, interagency partners, international partners and organizations, and non-governmental organizations.

\section{Notes}

1 The U.S. Department of Defense first defined irregular forces as "Armed individuals or groups who are not members of the regular armed forces, police, or other internal security forces" in 2009 in Joint Chiefs of Staff, 
Counterinsurgency Operations, JP 3-24 (Washington, DC: Joint Chiefs of Staff, October 5, 2009), GL-7, but rescinded the definition with the 2013 edition of the joint publication.

2 Lisa Saum-Manning, VSO/ALP: Comparing Past and Current Challenges to Afghan Local Defense (Santa Monica: RAND, 2012), 2.

3 Thomas Barfield, Afghanistan: A Cultural and Political History (Princeton: Princeton University Press, 2012).

4 Ibid., 338.

5 Ibid.

6 Saum-Manning, VSO/ALP, 3.

7 A Special Forces battalion has three Special Forces companies, each with six detachments.

8 A Provincial Reconstruction Team is a "civil-military team designed to improve stability in a given area by helping build the legitimacy and effectiveness of a host nation or local provincial government in providing security to its citizens and delivering essential government services," Joint Chiefs of Staff, Civil-Military Operations, JP 3-57 (Washington, DC: Joint Chiefs of Staff, 2018), GL-7.

9 “Kandahar Provincial Overview," Naval Postgraduate School, accessed December 28, 2020, https://nps.edu/web/ $\mathrm{ccs} /$ kandahar.

10 Azam Ahmed, "Powerful Afghan Police Chief Killed in Kabul," New York Times, March 20, 2015, www.nytimes. com/2015/03/20/world/asia/powerful-afghan-police-chief-killed-in-kabul.html.

11 Mathieu Lefevre, "The Afghanistan Public Protection Program and the Local Defence Initiative," in Snapshots of an Intervention: The Unlearned Lessons of Afghanistan's Decade of Assistance (2001-2011), ed. Martine van Bijlert and Sari Kouvo (Kabul: Afghanistan Analysts Network, 2012).

12 Saum-Manning, VSO/ALP, 5.

13 Human Rights Watch, "Just Don't Call It a Militia": Impunity, Militias, and the "Afghan Local Police" (New York: Human Rights Watch, 2011).

14 Robert M. Perito, Afghanistan's Civil Order Police: Victim of Its Own Success (Washington, DC: United States Institute of Peace, 2012).

15 See, for example, Donald C. Bolduc, "Organizing Counterinsurgency Operations in Afghanistan," Small Wars Journal, August 5, 2008, https://smallwarsjournal.com/jrnl/art/organizing-counterinsurgency-operations-inafghanistan; Jim Gant, One Tribe at a Time: The Paper That Changed the War in Afghanistan (New York: Black Irish Entertainment, 2009).

16 Seth Jones, In The Graveyard of Empires: America's War in Afghanistan (New York: Norton, 2009).

17 Ibid.

18 Malou Innocent, "Five Reasons to Withdraw From Afghanistan," National Interest, March 21, 2012, https://nationalinterest.org/blog/the-skeptics/5-reasons-withdraw-afghanistan-6673.

19 Office on Drugs and Crime, Corruption in Afghanistan: Recent Patterns and Trends (Vienna: United Nations, 2012).

20 Liam Collins, "Military Innovation in War: The Criticality of the Senior Military Leader" (PhD diss., Princeton University, 2014), 306-412.

21 Stanley McChrystal, ISAF 2009 Comprehensive Counter Insurgency Strategy (Kabul: ISAF, 2009); Kenneth Katzman, Afghanistan: Post-Taliban Governance, Security, and U.S. Policy, CRS Report No. 30588 (Washington, DC: Congressional Research Service, 2009).

22 For more on the Commando Corps, see Eric Sof, "ANA Commando: An Elite Afghanistan Special Operations Forces," SPEC OPS Magazine, December 3, 2020, https://special-ops.org/afghanistan-ana-commando-special-forces/.

23 Eventually the school became the Afghan National Army Special Operation Advisory Group.

24 Yochi J. Dreazen, “Going Native," National Journal 42, no. 46 (2010).

25 Department of Defense, Report on Progress Toward Security and Stability in Afghanistan (Washington, DC: Department of Defense, 2011), 68.

26 A shaping operation is "an operation that establishes the conditions for decision operation through effects on the enemy, other actors, and the terrain." See Department of the Army, Operations, ADRP 3-0 (Washington, DC: Department of the Army, 2016), 4-6.

27 See, for example, Eugene G. Piasecki, “Civilian Irregular Defense Group: The First Years: 1916-1967,” Veritas 5, no. 4 (2009): 19-28.

28 Mark Moyer, Village Stability Operations and Afghan Local Police (MacDill AFB: JSOU, 2014), 9-10, www.socom. mil/JSOU/JSOUPublications/JSOU14-7_Moyar_VSO_FINAL.pdf.

29 Ibid., 12-13.

30 Megan Katt, "Blurred Lines: Cultural Support Teams in Afghanistan," Joint Forces Quarterly 75, no. 4 (2014): 106-113.

31 This came from various intelligence reports. 


\section{Special Operations and Afghan police}

32 Keith Shawe, Afghanistan in 2013: A Survey of the Afghan People (Kabul: The Asia Foundation, 2013), 9, https:// asiafoundation.org/resources/pdfs/2013AfghanSurvey.pdf.

33 Bill Roggio, “Full Text of General Petraeus’ Testimony to Congress,” Threat Matrix (blog), March 15, 2011, www. longwarjournal.org/archives/2011/03/full_text_of_general_petraeus.php.

34 Moyar, VSO and the ALP, 51.

35 Saum-Manning, VSO/ALP, 2012.

36 Moyar, VSO and the ALP, 14.

37 Curtis Buzzard, e-mail, October 8, 2020.

38 Ibid.

39 Gerald Fulcher and Alec Mackenzie, "Building a Viable Local Security Force," Diplomatic Courier, February 12 , 2012, www.diplomaticourier.com/posts/building-a-viable-local-security-force.

40 OECD, Aid Effectiveness 2011: Progress in Implementing the Paris Declaration (Paris: OECD, 2012).

41 Afghan NGO Safety Office, ANSO Quarterly Data Report, Q.4 2011 (London: INSO, 2011).

42 Fulcher and Mackenzie, "Building a Viable Local Security Force."

43 David H. Petraeus, conference remarks, CFSOCC-A Village Stability/Afghan Local Police Conference, April 9, 2011.

44 Anthony Cordesman, The Afghan War in 2013: Vol III: Security and the ANSF (Washington, DC: Center for Strategic and International Studies, 2013), 115.

45 Enduring Strategic Partnership Agreement between the Islamic Republic of Afghanistan and the United States of America, May 2, 2012, https://obamawhitehouse.archives.gov/sites/default/files/2012.06.01u.s.-afghanistanspasignedtext.pdf.

46 Cordesman, The Afghan War, 115.

47 Alia Chughtai, “Afghanistan: Who Controls What,” Al Jazeera, June 24, 2019, www.aljazeera.com/news/2019/6/24/ afghanistan-who-controls-what. 